\title{
Cosmo-agonia ${ }^{1}$
}

\begin{abstract}
Valmir Santos
\section{Resumo}

A criação do espetáculo Orfeu mestiço: uma hip-hópera brasileira reflete amadurecimento de linguagem do Núcleo Bartolomeu de Depoimentos em sua primeira década de história. Dramaturgia e encenação incorporam referências tradicionais das culturas populares, de tradições indígenas, negras e camponesas, em simbiose com os elementos da cultura hip-hop que marcam os grandes centros urbanos.
\end{abstract}

No limiar da sua segunda década de história, o Núcleo Bartolomeu de Depoimentos elabora na cena a passagem dos tempos próprio e ancestral. Em Orfeu mestiço: uma hip-hópera brasileira, parte dos atores remanescentes da origem do grupo, no ano de 2000, inscreve no corpo, na palavra, na voz, na escuta e na percepção de mundo a maturidade colhida no percurso. O traço mais distintivo nesse novo trabalho é a capacidade de deslocamento da urgência da cultura urbana do asfalto, burilada como linguagem, para o chão das tradições populares, principalmente das bordas rurais, desbravando outras pulsações e saberes do Brasil também índio, negro, caboclo, camponês.

O caminho não é exatamente novo, se considerada a afirmação da ascendência africana, portanto afro-brasileira, na base dos espetáculos e intervenções anteriores. Releituras de romance, poesia ou dramaturgia clássica, além de dramaturgia vertida essencialmente do seio do grupo, essas variantes do repertório sempre assimilaram, em alguma medida, aspectos culturais e sagrados. Agora, o coletivo avança, temática e formalmente, na extensão do território imaterial, alcançando contornos de uma nação quilombola, maracatu, irmanada. A fala-canto e o gesto-sonoro dos centros e periferias metropolitanas saíram do eixo primordial da cena para coexistir com outros vetores da formação brasileira, tornando os processos assumidamente mais complexos e anacrônicos, no sentido do tempo disposto e lido em fragmentos.

Para um projeto gestado na cidade de São Paulo, coração do capitalismo financeiro no país, é notável a abertura desses artistas para conversar com a tradição 
de outras paragens sem folclorizá-la, implicando, naturalmente, o que ela possui de desordem, como observa Antônio Risério:

Folclore é uma invenção das elites dirigentes, que foram etnia dominante na colonização do Brasil. Não existe folclore, existe cultura. Quando falamos em tradição, é melhor situar o problema num quadro mais amplo. O que interessa é a apropriação de realidades distantes, seja no tempo ou no espaço, verificando o modo como essa apropriação se dá em função de um presente social e com que objetivo ela se processa. (Risério, 1998, p. 250)

A dramaturgia e a direção assumem as quebras narrativas, a superposição de vozes, de imagens, o naco de fábula, a gravidade da pauta histórica revisitada - a ditadura cívico-militar -, enfim, estilhaçam a expectativa do gênero musical, quando se trata de Núcleo Bartolomeu, e permitem divisar outras partituras poéticas para além da cena. A autorrepresentação convicta em Acordei que sonhava, de 2003, e em Frátria amada Brasil: pequeno compêndio de lendas urbanas, de 2006, dessa vez soa apascentada, sem prejuízo da contundência, ao contrário.

O dilaceramento também é depreendido nas miudezas. A dor do outro fica patente na mediação do idealista e depois juiz Orfeu, em sua sede de justiça amortecida e depois reavivada; da brava professora Eurídice que não se deixa subjugar ao menor obstáculo, vide a determinação em erradicar o analfabetismo ou combater o regime opressor. Eles, Orfeu e Eurídice, a despeito da aura mítica presumida, se revelam personagens plausíveis e palpáveis no imaginário do povo brasileiro, esse oceano. O argumento tece, nos planos da realidade, da memória e do imaginário, a trajetória de um homem colocada no retrovisor ao receber a notícia da exumação do corpo da mulher desaparecida, precipitando sombras e infernos que não foram apagados.

Identidade, nação... A essa altura, "antropologizar"2 o teatro, e vice-versa, pode ser uma livre associação atentadora. Porém, a escola de Eugenio Barba não constitui premissa nos procedimentos do grupo paulista adepto da estrutura épica desde que veio ao mundo. Ainda assim, Orfeu mestiço abre uma fresta considerável nessa perspectiva, provavelmente consciente. A interdisciplinaridade faz com que o sincretismo ritual tateado em experiências como Manifesto de passagem: 12 passos em direção à luz, de 2007, uma evocação à heteronomia de Fernando Pessoa, floresça aqui organicamente, dando lastro ao sujeito histórico e assegurando-Ihe alguma unidade de subjetivação nas franjas do distanciamento. Há uma interioridade espiritual, um tom hierático no modo como os personagens e as figuras da peça resistem e insistem em

\footnotetext{
2 "Assim como o teatro está se antropologizando, a antropologia está se teatralizando". Schechner, Richard. (In: Pavis, 1999, p. 17).
} 
tomar as rédeas diante dos contratempos vindos de fora, advindos da realidade invariavelmente em estado bruto.

São as atrizes protagonistas, mesmo quando em papéis masculinos (longe de reduzir à questão de gênero), as âncoras desses estados cosmogônicos que perpassam os elementos documentais e realistas dos quais essa história também é provida. Daniela Evelise (como Eurídice), Roberta Estrela D’Alva (como mestre de cerimônia, MC, e Griot) e Luaa Gabanini (como Maria Alice, Mãe do Dops) conspiram para desviar dos códigos fortíssimos da palavra e da música na cultura hip-hop: uma poesia outra, uma instância paralela e mais profunda entre a forma e o instante de criação. E esse horizonte é artaudiano:

Os processos mentais colocam em jogo forças elementares que estão na origem do cosmos. De um combate primordial, que o poeta vive em si mesmo, emergem as formas, que serão, por sua vez, devoradas por esse mesmo fogo. As palavras são expressões temporárias e evanescentes de um processo que lhe é subjacente. $\mathrm{O}$ ato artístico repete, num certo nível, o ato mítico da criação. Daí a proximidade entre a arte e o rito. (Quilici, 2004, p. 102).

As cosmogonias pedem ritualizações e a celebração órfica na escrita e na direção de Claudia Schapira potencializam esse lugar. Para tanta agonia que acomete o cidadão e o país em sua linha histórica, nos séculos de memória escrava ou nas analogias da contemporaneidade, há um eu-lírico, um nós-lírico que ajudam a suplantar com arte.

Observando o panorama retrospectivo do núcleo a partir da plataforma de 2012 , o atual resultado parece mais representativo do que as produções citadas, quando imbuídas da discussão da identidade no país. Em Orfeu mestiço, a edição do vasto material levantado em cerca de três anos de pesquisa valoriza o discurso por meio da cena. A consciência crítica não está restrita à persuasão do rap. O silêncio é tão rumoroso quanto. Um blues sincopado pinta no ar a melancolia existencial do jovem Orfeu em seu labirinto, no que a interpretação acústica de Cristiano Meirelles, investida de sutilezas, dialoga com o seu duplo na vida adulta, por Eugênio Lima, DJ com contornos de pensador mesmo quando postado atrás dos toca-discos.

A disposição dominantemente coral e musical da cena de Orfeu mestiço guarda parentesco com a historiografia teatral brasileira em criações que retrataram grandes painéis históricos, políticos e sociais, justo no período da ditadura. Basta lembrar de Arena conta Zumbi e Arena conta Tiradentes, dobradinhas de Augusto Boal e Gianfrancesco Guarnieri; de Morte e vida Severina, o poema épico de João Cabral de Melo Neto musicado por Chico Buarque; ou ainda a Feira Brasileira de Opinião, que reunia textos de drama- 
turgos de proa, prenunciava manifestos diante do estado de coisas e, claro, foi censurada. Décio de Almeida Prado assim resumiu as peças ali previstas e depois publicadas em livro:

Falam de índios que são expulsos das matas pela civilização, de loterias esportivas e seus improváveis ganhadores, de perseguidos políticos que se despedem das amadas ao som de feiras livres e não de cotovias shakespearianas, de linchamentos realizados sem ao menos uma autêntica convicção sanguinária, de pobres camponeses explorados na cidade grande, de falsos moralistas, de publicitários que escondem no trabalho as suas frustrações morais e intelectuais, de um imenso túnel escuro que estaríamos atravessando... (Prado, 1978, p. 14)

No subtexto ideológico do Núcleo Bartolomeu, o braço erguido e o punho cerrado alinham-se à causa da revolução, em seu sentido pleno, pelos que tombaram lutando contra regimes de exceção no passado, em defesa dos direitos humanos, políticos e sociais. A causa é ressignificada diante dos paroxismos da democracia no século $X X I$, suas fissuras violentas, por vezes, mais cruéis do que nos anos de chumbo - o engajamento do Movimento dos Trabalhadores Sem Terra e os resquícios do coronelismo estão entre os exemplos de atualização. Os versos do prólogo já evidenciam o desejo artístico de incitar "A quem nos assiste,/ a se juntar à nossa insistência-teatro/ por dizer o indizível/ Por dar forma ao indefinível/ Levantando o estandarte (trágico se não fosse cômico) da encenação".

É nas raias da inventividade cênica que o coletivo mergulha para renovar fôlego. A polissemia de lei nas expressões sonoras e vocais vê acrescentada uma poderosa camada de projeções em vídeo por entre os filós que vão e vêm no cenário de Daniela Thomas. A iconografia de Tatiana Lohmann e ZoomB Laboratório Audiovisual amplia o efeito sampleador do que é memória e ato interativo com o espectador. Esses tules transparentes tiram o véu da história, fornecem documentos ou subsidiam a ficção.

Nessa liturgia, os músicos-ogãs do conjunto Treme Terra apoiam os ritos com sua energia juvenil cúmplice nos desfazimentos dos quadros não-lineares. Caminham, cantam e seguem a canção (Geraldo Vandré é citado diretamente) sob a órbita da contadora Estrela D’Alva, que faz as vezes de corifeu ou griot, como se postada simbolicamente à frente de um congá. As atuações de Estrela D’Alva e Gabanini são oferendas à parte na ventura desse espetáculo. Como cofundadoras do grupo, as atrizes permitem verificar a evolução de seus registros, a apropriação de nuances outrora ofuscadas pela incisão do gesto ou da voz na figura do MC.

Ambas pulsam esse domínio técnico e poético no momento em que se desdobram na respiração de Eurídice diante dos fantasmas pós-decretação do Al-5, equa- 
lizando a quimera e a tragédia conforme uma Antígona, uma Ifigênia ou uma Medeia tomadas por palavras-sintomas, premonitórias, sacrificais, atávicas. Essa composição sintetiza a ascensão de Luaa Gabanini como a mãe italiana anarquista que delata o envolvimento da filha com a guerrilha, por temer sua vida, contradição instintiva da qual não se arrepende ou se justifica. Roberta Estrela D’Alva também abre as portas para consolidar o perfil multifacetado de seu mestre de cerimônias de extrações indígenas, negras, no limite do transe e das habilidades performativas que a atriz domina com peculiaridade. Sua fé é de artesã, como ilustra Marcelo Moura Mello para lembrar o apuro dos quilombolas ao sagrar as rodas:

Como a mão do oleiro na argila, o narrador imprime sua marca na narrativa, seja por sua gestualidade, que sustenta o fluxo do que é dito, seja pelos ensinamentos morais que as experiências tecidas por sua narração contêm. (Moura, 2012, p. 74).

Na invocação e culto aos antepassados indígenas, a atriz Daniela Evelise complementa a travessia da peça em honra aos espíritos dos mortos. Sua Eurídice absorve a sabedoria ancestral na práxis cidadã, em que pese o trágico desaparecimento sob tortura. Ao final, a atriz entoa um canto que já não pertence tão somente à mitologia, mas à mística. Um canto da etnia yny karajá em saudação ao massacre dos sem-terra em Eldorado dos Carajás, no Pará. Nesse desfecho, em questão de minutos, desenha-se a gênese sangrenta do Descobrimento do Brasil perpetuada na aldeia, no campo e no asfalto. Além da denúncia, o espetáculo se permite acessar o poder da diversidade cultural deste solo que "a cada passo do tempo está sendo lapidado", e a duras penas, como o teatro pode sentir, cantar, falar e pensar.

\section{Bibliografia}

Mello, Marcelo Moura. Reminiscências dos quilombos: terreiros da memória em uma comunidade negra rural. São Paulo: Editora Terceiro Nome, 2012.

Prado, Décio de Almeida (prefácio). Feira brasileira de opinião: a feira censurada. Vários autores. São Paulo: Global Editora, 1978.

Quilici, Cassiano Sydow. Antonin Artaud: teatro e ritual. São Paulo: Annablume/Fapesp, 2004. Risério, Antônio. Ovo novelo: ovo novo no velho. In: Miranda, Danilo Santos de (coord.). Arte pública. São Paulo: Sesc, 1998.

Schechner, Richard. In: Pavis, Patrice. Dicionário de teatro. São Paulo: Editora Perspectiva, 1999. 